\title{
Comparative Analysis and Performance Investigation Of Single-Phase Improved Power Quality Converter
}

\author{
Baziga youssuf ${ }^{1}$, Sami Jan Lolu ${ }^{2^{*}}$ \\ Assistant Professor, Dept. of Electrical Engineering, \\ Islamic University of Science And Technology, PULWAMA $(J \& K)^{1,2}$ \\ Email: bazii007@gmail.com ${ }^{1}$, sami.jan@islamicuniversity.edu.in ${ }^{2}$
}

\begin{abstract}
This paper deals with the comparative analysis and performance investigation of single-phase improved power quality converters to compensate the harmonics of non-linear load in order to improve the power quality. The comparative analysis of various IPQC topologies and detailed performance investigation of unidirectional boost converter has been done. Various simulations have been presented under the steady state for comparative performance evaluation to achieve better utilization and control of IPQCs. The results show an inherent power quality improvement in terms of reduced Total Harmonic Distortion (THD) of source current and Power Factor Correction (PFC) properties to a large extent. The simulation results have been further aided and confirmed by experimental results obtained on a hardware prototype of a single phase, unidirectional AC/DC boost-converter.
\end{abstract}

Keywords- Improved power quality converters (IPQCs), Total harmonic distortion (THD), Power Factor Correction (PFC), Switch mode power supply (SMPS), Electromagnetic interference (EMI) and Radio frequency impedance (RFI).

\section{INTRODUCTION}

An ac to dc converter is a necessary part of any power supply unit utilized as a part of the every electronic hardware. Additionally, it is utilized as an interface between utility and the majority of the power electronic supplies. These electronic supplies frame a noteworthy piece of load on the utility. For the most part, to convert line frequency ac to dc, a diode bridge rectifier is utilized. To diminish the swell/ripples in the dc yield voltage, a substantial filter capacitor is utilized at the rectifier yield. In any case, because of this filter capacitor, the current drawn by this converter is peaky in nature. This input current is rich in low order harmonics. Likewise, as power electronic supplies are progressively being utilized as a part of power conversions, they infuse low order harmonics into the utility. Because of the appearance of these harmonics, the total harmonic distortion (THD) is high and the input power factor (IPF) is poor. Because of issues connected with low power factor and harmonics, utilities will uphold harmonic guidelines and rules which will restrain the measure of current distortions permitted into the utility and in this manner the diode rectifiers may not be used. In order to overcome the limitations of phase controlled converters, Improved Power Quality Converter (IPQC) are proposed. These mostly employ an AC/DC rectification stage followed by a DC to DC conversion stage for effective voltage control. DC to DC converters [1] when connected across a rectified $\mathrm{AC}$ line, exhibit an inherent power factor correction property.
The main motivation behind this work is to design a prototype of IPQC that solves power quality problem [2] otherwise introduced by conventional converter. The challenges to be faced in the design of such AC/DC power supply are in achieving:
a) high power factor,
b) low THD,
c) high efficiency along with particular line and load conditions,
d) high power density or reduced size,
e) high reliability, and
f) low system cost

\section{POWER FACTOR CORRECTION AND ITS USES}

Decrease of line current harmonics is required so as to follow the standard. This is commonly referred to as the power factor correction - PFC, which may be misdirecting. At the point when an electric load has a PF lower than 1, the apparent power conveyed to the load is more prominent than the genuine active power that the load devours. Just the active power is equipped for doing work, however the apparent power decides the measure of current that streams into the load, for a given load voltage. Power factor correction (PFC) is a strategy of neutralizing the undesirable impacts of electric loads that make a power factor (PF) that is under (1). The power factor is characterized as the proportion of the active force $\mathrm{P}$ to the apparent force $\mathrm{S}$ :

$$
P F=\frac{P}{S}
$$




\section{Available online at www.ijrat.org}

For simply sinusoidal voltage and current, the traditional definition is acquired:

(2)

$$
P F=\cos \phi
$$

Where $\cos \varphi$ is the displacement factor of the voltage and current. In traditional sense, PFC implies pay of the "displacement factor". The line current is nonsinusoidal when the load is nonlinear. For sinusoidal voltage and non sinusoidal current the PF can be communicated as:

$$
P F=\frac{V r m s \times I 1 \mathrm{rms}}{V r m s \times I r m s} \cos \emptyset=\frac{I 1 r m s}{I r m s} \cos \emptyset=K p \cos \emptyset
$$

$$
K_{P}=\frac{I 1 r m s}{I r m s}, K p \epsilon[0,1]
$$

$\mathrm{Kp}$ depicts the harmonic component of the current as for the fundamental.

Subsequently, the power factor relies on upon both harmonic component and displacement factor. $\mathrm{Kp}$ is alluded to as purity factor or distortion factor. The total harmonic distortions $\left(\mathrm{THD}_{\mathrm{i}}\right)$ is characterized as:

$$
T H D_{i}=\frac{\sqrt{\sum_{\mathrm{n}=2}^{\infty} \mathrm{In}^{2}} r m s}{\mathrm{I} 1 \mathrm{rms}}
$$

Subsequently the connection in between $\mathrm{Kp}$ and THDi is

$$
K_{P}=\frac{1}{\sqrt{1+\mathrm{THD}^{2}}}
$$

\subsection{Advantages Of Power Factor Correction (PFC): \\ 1. Current distortion is diminished. \\ 2. All the power is active. \\ 3. Little RMS current. \\ 4. Higher number of loads can be nourished.}

\subsection{Uses of PFC:}

1. Power industry: Power factor correction of linear loads.

2. Switched mode power supply: Power factor correction of non-linear loads.

\subsection{Power Factor Correction Techniques}

The multiplication of the power converters draw throbbing input current from the utility line, this not just lessen the input power factor component of the converters but additionally infuses a lot of harmonic currents into the utility line. To enhance the power quality, different PFC plans have been proposed. There are harmonic standards, for example, IEC 1000-3-2 presented for enhancing power quality. Due to The introduction of these harmonic norms, now power supply manufacturers have to follow these norms strictly for the of signal interference problem. The different techniques for power factor correction can be named as:

(a) Passive power factor correction techniques (b) Active power factor correction techniques

In passive power factor correction [3] systems, a LC channel is embedded between the AC mains line and the input port of the diode rectifier of AC/DC converter as indicated in Figure. 2. This strategy is basic and rough however it has cumbersome size and overwhelming weight and the power factor can't be high. Subsequently it is presently not relevant for the present patterns of harmonic standards. By introducing the regulation standards IEC 1000-3-2 active power factor correction technique is utilized now a day. There are distinctive topologies for executing active power factor remedy procedures. Essentially in this strategy power factor adjusting cell is utilized for following the input current in period of input voltage such that input power factor come up to solidarity. Contrasting to the passive power factor correction techniques, active PFC methods have numerous favorable circumstances, for example, high power factor, diminished harmonics, littler size and light-weight. Then again, the complex and expensive nature are the fundamental disadvantages of this methodology.

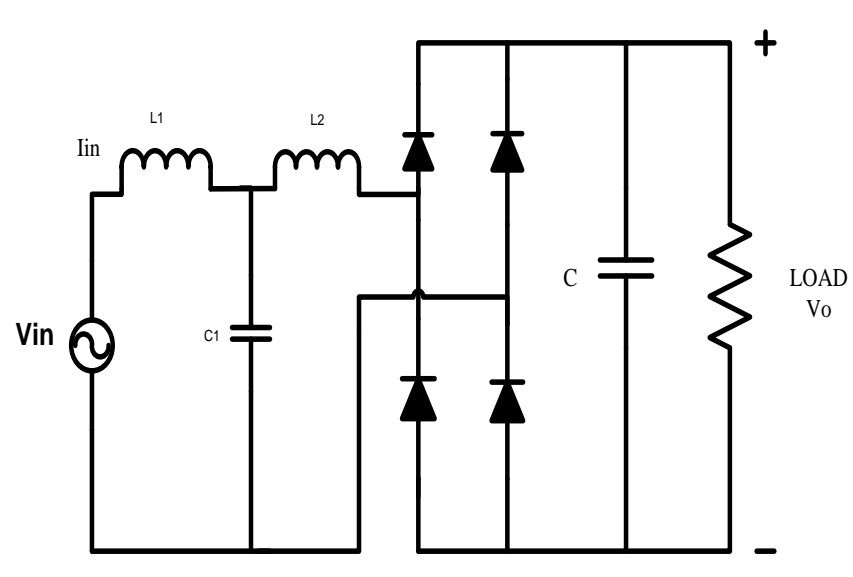

Figure2. Passive PFC Technique

The active PFC procedures can be named as:

a) PWM power factor correction methods.

b) Resonant power factor correction methods.

c) Soft switching power factor correction methods.

In PWM power factor correction approach, the power switching device works at pulse widthmodulation mode [3]. Essentially in this procedure switching frequency of active power switch is consistent, yet turn-on and turn off mode is variable. The advantage points are basic arrangement, simplicity of analysis and control, minimal voltage and current anxiety. In this manner it is widely utilized as a part of PFC circuits. For the minimization of converter size PWM procedure 


\section{Available online at www.ijrat.org}

produces huge switching losses. Diverse topologies of PWM systems are as per the following:
(a) Buck type.
(b) Flyback type
(c) Boost type.
(d) Cuk type.

\section{IMPROVED CONVERTERS \\ POWER QUALITY}

The IPQC innovation has been created now at a sensibly developed level for ac / dc change with diminished harmonic flows, high power factor, low electromagnetic interference (EMI) and radio frequency impedance (RFI) at input ac mains and very much managed and great quality dc

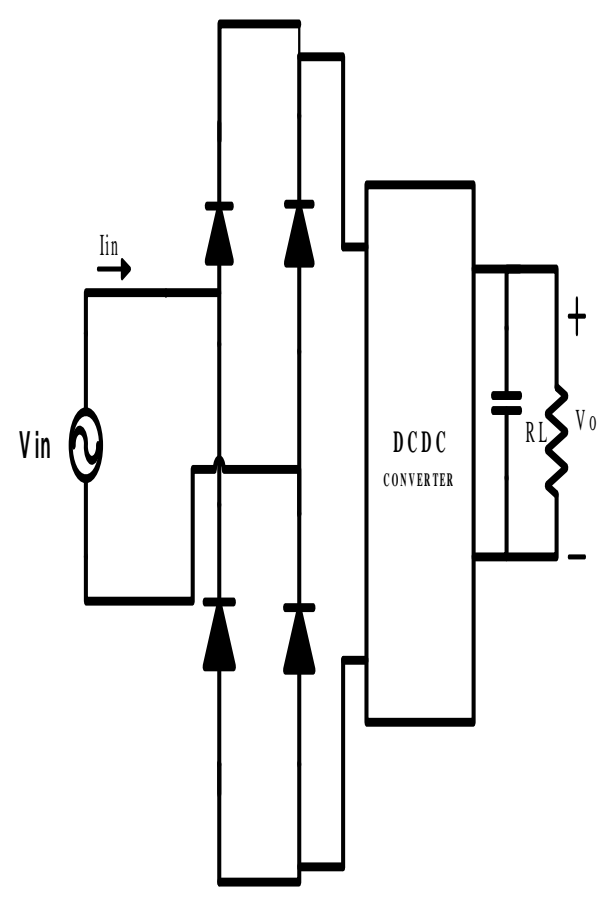

Figure3. Active PFC Technique

yield to nourish loads running from few of Watt to a few hundred kilowatts power appraisals in extensive number of utilizations (figure 3 ). It has been altered in the last couple of decade with differing arrangements, control approaches, solid state gadgets, circuit incorporation, changing magnetic, and so on., for components, for example, boost, buck, buck-boost, and multilevel with unidirectional and bidirectional power flows. An expansive number of IPQC designs have been advanced to suit immensely differing prerequisites of diverse applications while keeping up a high level of value at the input ac source and output dc loads. Improved power Quality Converters are being created with unidirectional and bidirectional power flow abilities. Three-stage unidirectional IPQCs are acknowledged utilizing a three-stage diode bridge took after by step down chopper, step up chopper, step down/up chopper, isolated, forward, flyback, push-pull, halfbridge, full-bridge, SEPIC, Cuk, Zeta, and multilevel converters. A high-frequency separation transformer offers diminished size, weight, expense, appropriate voltage coordination and isolation. Then again, threestage bidirectional IPQCs comprise of fundamental converters, for example, push-pull, half-bridge, voltage source converter (VSC) topology, or current source converter (CSC) topology. Four-quadrant three phase AC/DC power converters are regularly actualized utilizing network converters. Because every one of these points of interest, IPQCs have created enormous enthusiasm among the specialists and application designers to take care of the expanding power quality issues. Indeed, when an application designer is at a choice stage, the active arrangement is beneficial over the passive filtering. [4]

\subsection{Converter topologies}

Extensively, Three-stage improved power Quality Converters (figure 3.1) have been arranged on the premise of the converter topology as Boost, Buck, Buck-Boost and Multilevel converters with unidirectional and bi-directional power flows and the kind of converter utilized as unidirectional and bidirectional converters.[5-8]

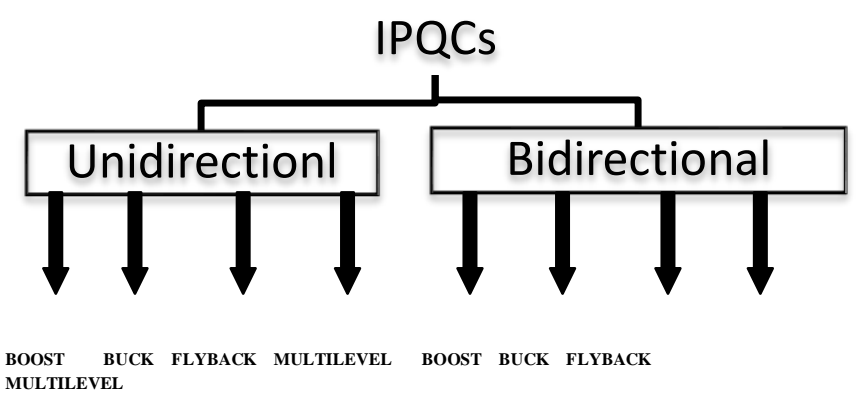

Figure3.1. Classification of improved power quality converters

\section{SYSTEM MODELING AND DESCRIPTION}

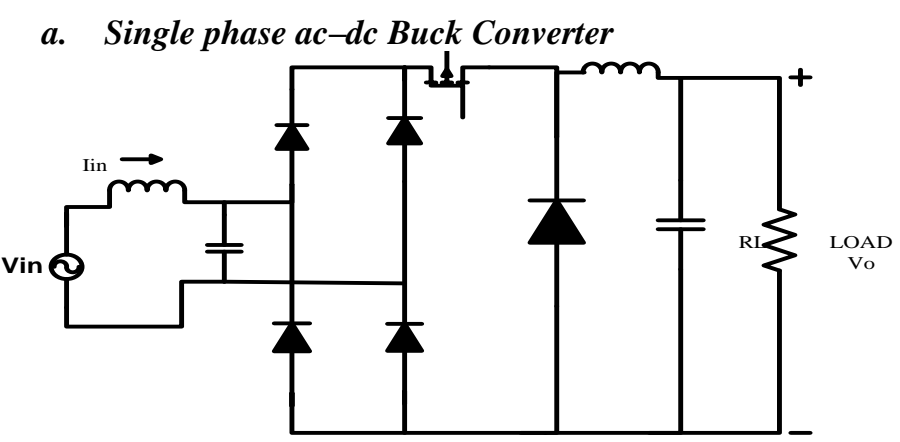

Figure4.1. Buck type topology 


\section{Available online at www.ijrat.org}

Buck converter is a combination of diode rectifier with step-down chopper along with the input and output filters .It produces a lower average output voltage than the $\mathrm{dc}$ input voltage and its main application is in regulated dc power supplies and dc motor speed control. The figure 4.1 shows a typical ac-dc buck converter. Input currents can be controlled in open as well as closed loop configurations; varying controllable $\mathrm{o} / \mathrm{p}$ dc voltage in both the cases. [9]

\subsubsection{Features:}

a) Power factor is very high.

b) AC mains have Low harmonic current.

c) Response is quick as compared to conventional semi-converters.

d) Size of ac and dc converters is very reduced.

e) Less stress on load and other components.

\subsubsection{Practical Applications:}

a) Small rating dc motor speed control.

b) Battery charging and high power rating can be achieved through use of GTO.

\subsubsection{Disadvantages:}

a) Input current drops to zero resulting in significant current distortion.

b) Input current has a discontinuous pulse waveform so that EMI is higher [10].

\subsection{SINGLE PHASE AC-DC BOOST CONVERTER}

Boost converter is a combination of diode bridge rectifier and step up DC chopper with filtering and energy storage elements (figure 4.2). Hysteresis current control techniques is used for control of inner current loop and wide bandwidth closed loop controllers in outer voltage loop of these converters to provide fast response and high level of power quality at input ac mains and dc output. These IPQCs provide well regulated dc output voltage even under wide varying ac input voltage from 90 to $300 \mathrm{~V}$ and frequency ranging from 40 to $70 \mathrm{~Hz}$ or dc input resulting in the concept of universal input in the number of applications. [11]

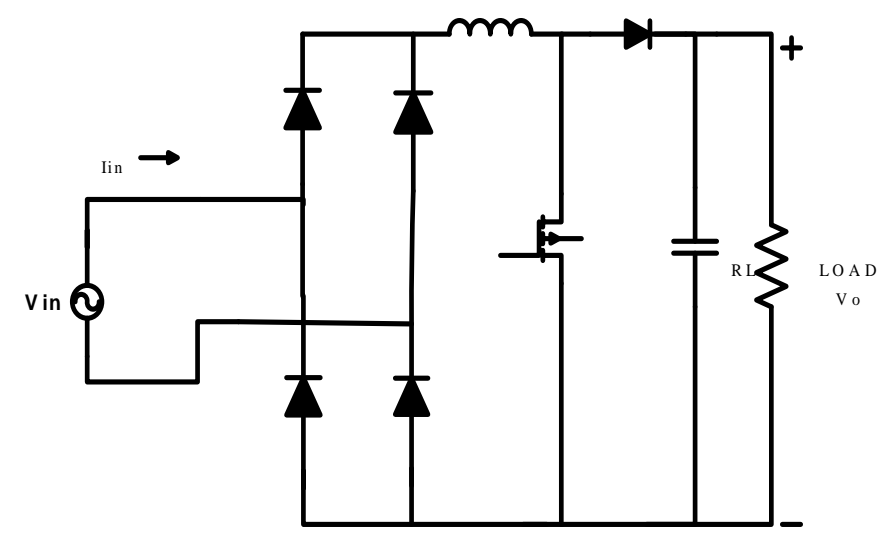

Figure 4.2. Boost type topology

\subsubsection{Features:}

The boost type topology so far is the most popular cofiguration because:

a) The input current is the inductor current and is therefore easily programmed by current mode control.

b) The boost inductor is in series with the ac power line so that the input current has smooth waveform (at continous conduction mode), resulting in much less EMI and therefore reduced input filter requirements.

\subsubsection{Practical Uses:}

These converters are extensively used in electronic ballasts, power supplies, variable-speed ac motor drives in compressors, refrigerators, pumps, fans, etc.

\subsection{SINGLE PHASE AC-DC FLYBACK CONVERTER}

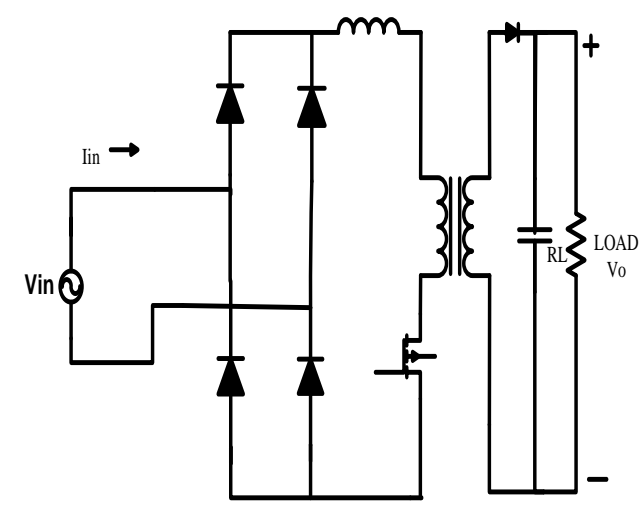

Figure 4.3. Flyback type topology

For low output power applications, Fly-back converter (figure 4.3) is the most commonly used SMPS circuit where isolation is provided for the output from the input main supply. In case of flyback type SMPS circuits the output power may vary from few watts upto100 watts. The circuit topology of this flyback converter is considerably much simpler than other SMPS circuits. At its input is generally an ac voltage followed by a simple capacitor filter circuit. 


\section{Available online at www.ijrat.org}

The flyback circuit [12] has an advantage that it can offer single or multiple isolated output voltages and has operation range over wide range of input voltage changes. In case of energy-efficiency and saving, flyback power supplies are not up to the mark as that of many other SMPS circuits but because of its simple topology and lower cost, makes it a popular candidate in low output power range. The easy commonly used fly-back converter makes use of a single controllable switch like MOSFET and the usual switching frequency is in the range of $100 \mathrm{kHz}$. If we go for the two-switch topology that offers better energy efficiency and less voltage stress across the switches but costs more and the circuit complexity also increases slightly.

\section{SIMULATION RESULTS}

Exhaustive simulation has been carried out in MATLAB Simulink environment to analyze an AC/DC Buck-converter, Boost converter and Flyback converter in maintaining a desirable power quality of source current as shown:

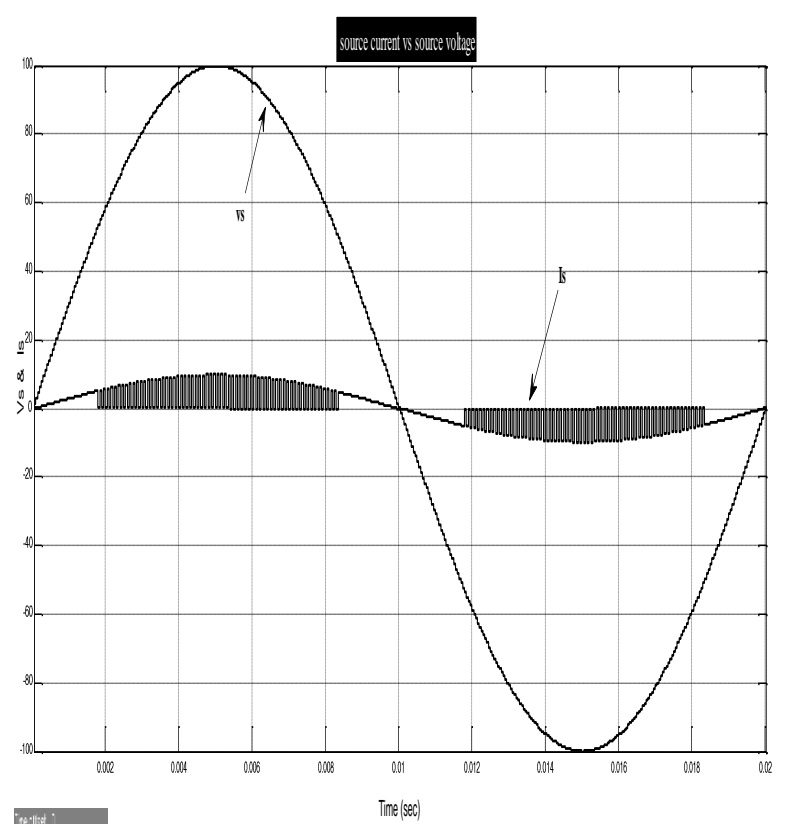

Figure5.1 (a)

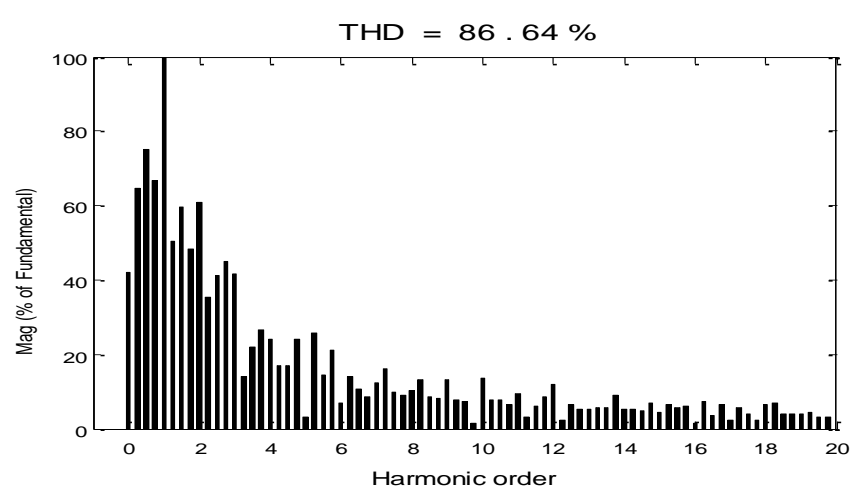

Figure5.1 (b)

Fig. 5.1 (a) Source Voltage and Source Current waveform (without Input Filter)in single phase ac-dc buck converter.

Fig. 5.1 (b) Harmonic spectrum of source current (without input filter) in single phase ac-dc buck converter.

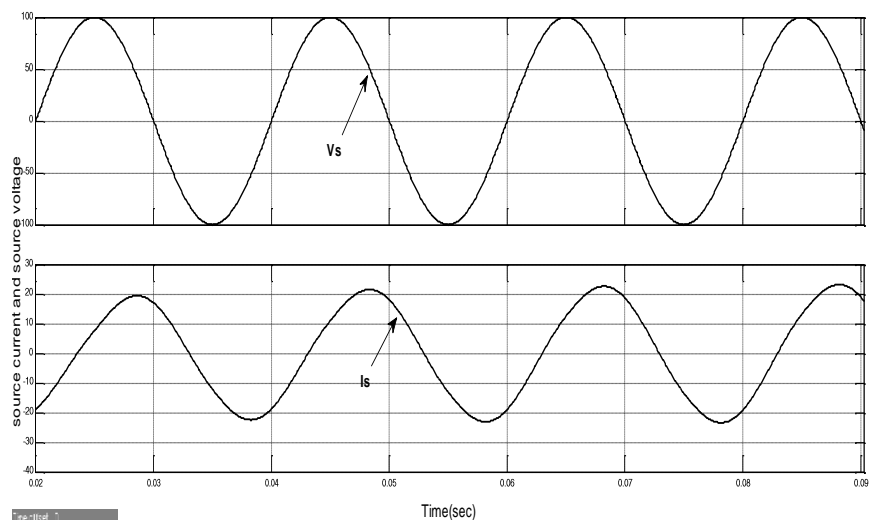

Figure5.2 (a)

$\mathrm{THD}=1.62 \%$

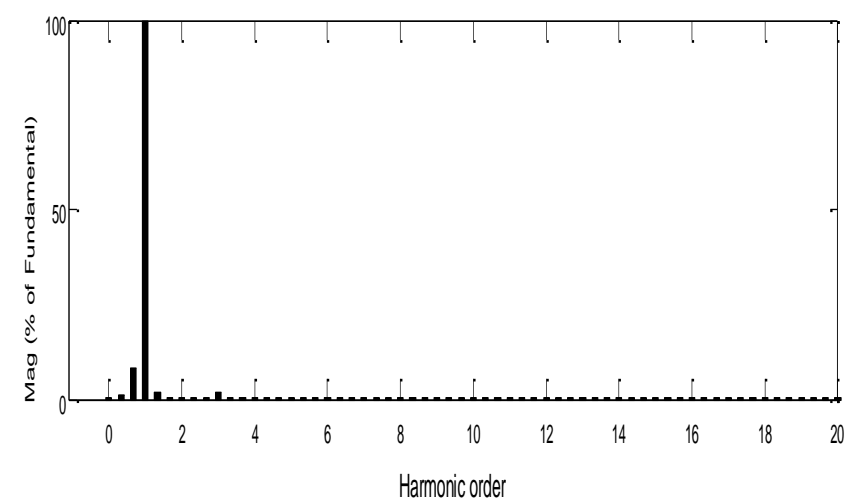

Figure5.2 (b)

Fig.5.2 (a) Source Voltage and Source Current waveform (with Input filter) in single phase ac-dc buck converter.

Fig.5.2 (b) Harmonic spectrum of source current (with input filter) in single phase ac-dc buck converter. 


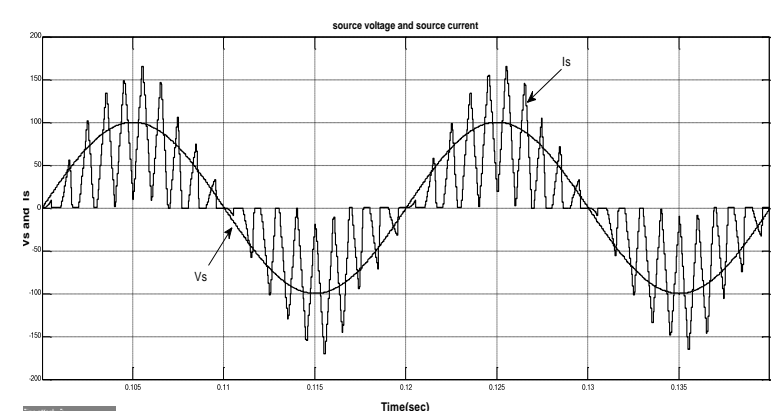

Figure 5.3 (a)

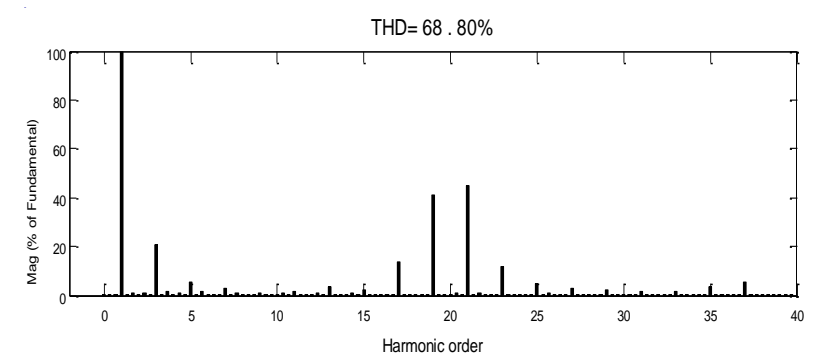

Figure 5.3 (b)

Fig.5.3 (a) Source Voltage and Source Current waveform (without Input Filter) in single phase ac-dc boost converter.

Fig5.3 (b) Harmonic spectrum of source current (without input filter) in single phase ac-dc boost converter.

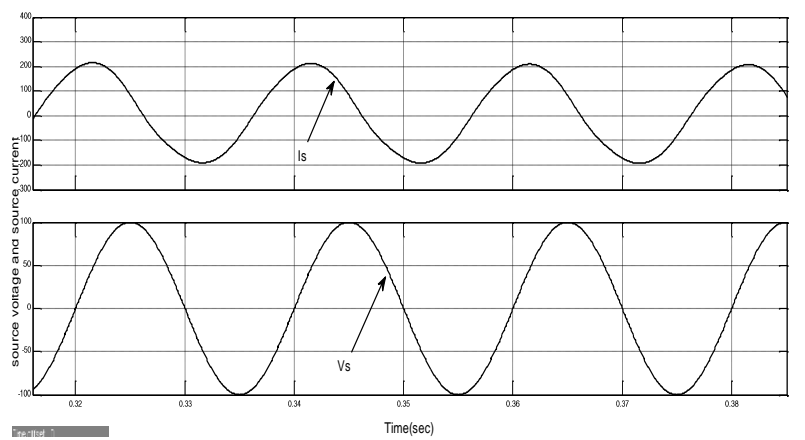

Figure5.4 (a)

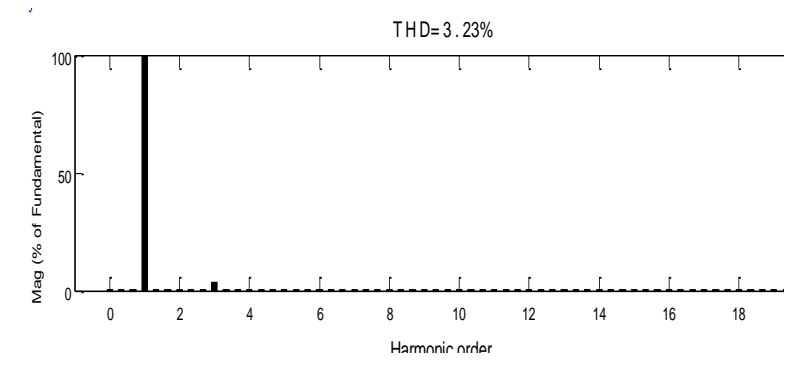

Figure5.4 (b)

Fig.5.4 (a) Source Voltage and Source Current waveform (with Input Filter) in single phase ac-dc boost converter

Fig.5.4 (b) Harmonic spectrum of source current (with input filter) in single phase ac-dc boost converter.

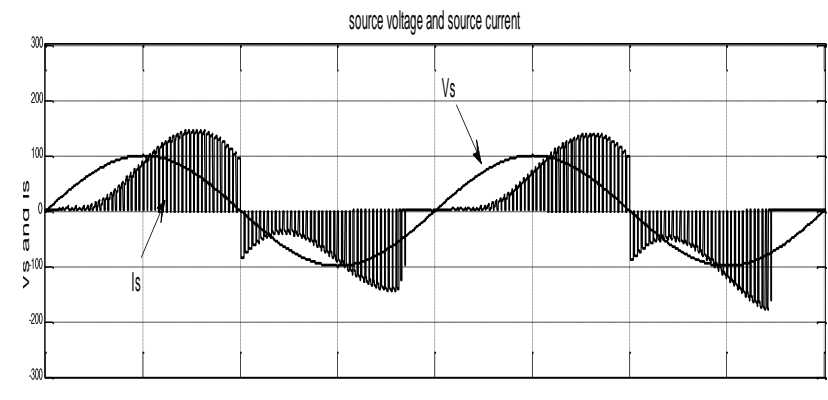

Time(sec)

Figure 5.5 (a)

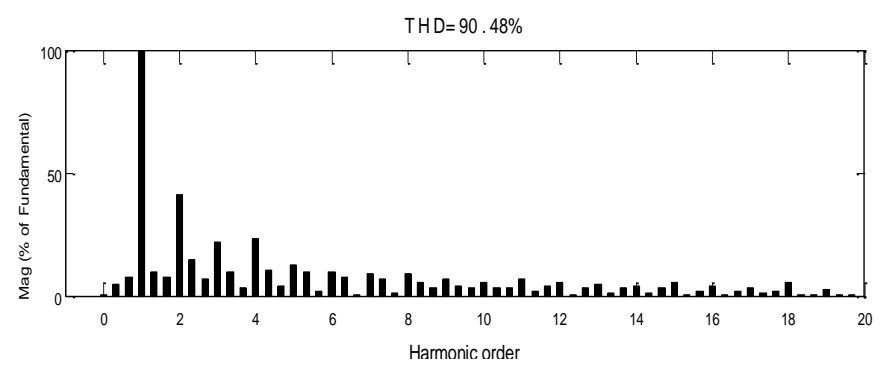

Figure5.5 (b)

Fig.5.5 (a) Source Voltage and Source Current waveform (without Input Filter) in single phase ac-dc flyback converter

Fig.5.5 (b) Harmonic spectrum of source current (without input filter) in single phase ac-dc flyback converter

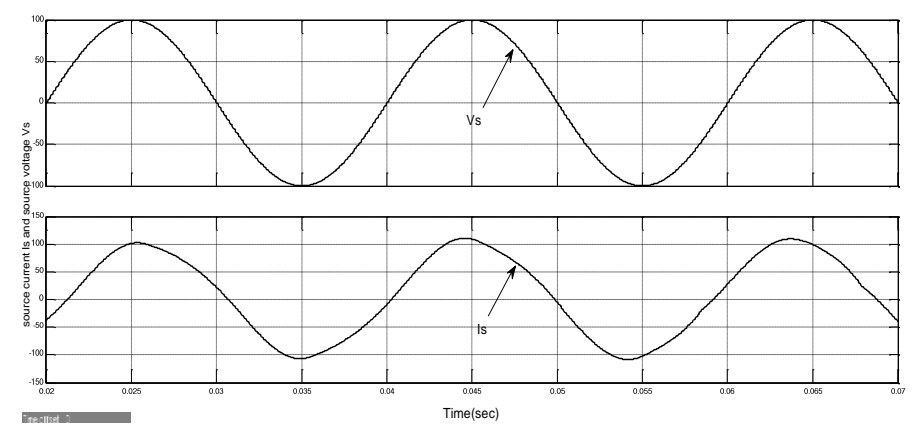

Figure5.6 (a)

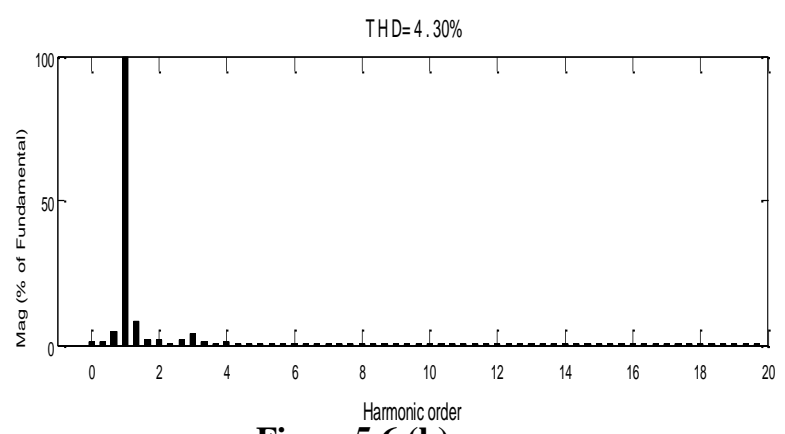

Figure5.6 (b)

Fig.5.6 (a). Source Voltage and Source Current waveform (with Input Filter) in single phase ac-dc flyback converter. 


\section{Available online at www.ijrat.org}

Fig.5.6 (b) Harmonic spectrum of source current (with input filter) in single phase ac-dc flyback converter.

\section{UNIDIRECTIONAL BOOST CONVERTERS FOR POWER QUALITY IMPROVEMENT}

Performance evaluation of unidirectional AC-DC boost converter deals with an extensive study of a boost-derived improved power quality converter, followed by its hardware implementation. The converter finds its application in variable frequency inverters, where it solves many power quality problems caused by the conventional power converters. A high DC link is possible through the said converter, besides low THD of source current and nearly unity input power factor.

The design (figure 6) involves the use of Hysteresis Current Control Technique, which has been implemented by means of a DSP device, thereby achieving a nearly pure sinusoidal source current.

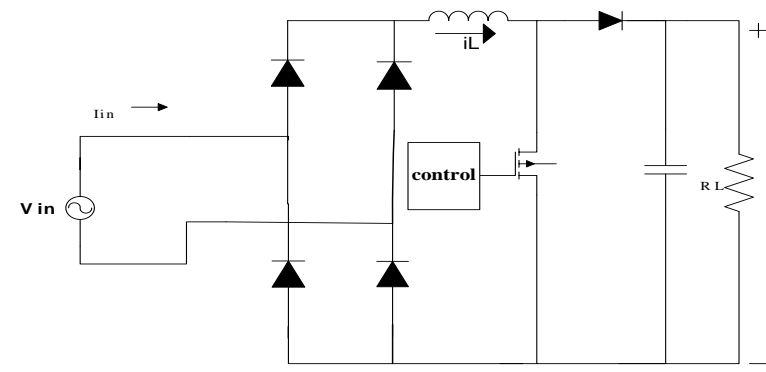

Figure6. Unidirectional boost converter using $\mathrm{HCC}$

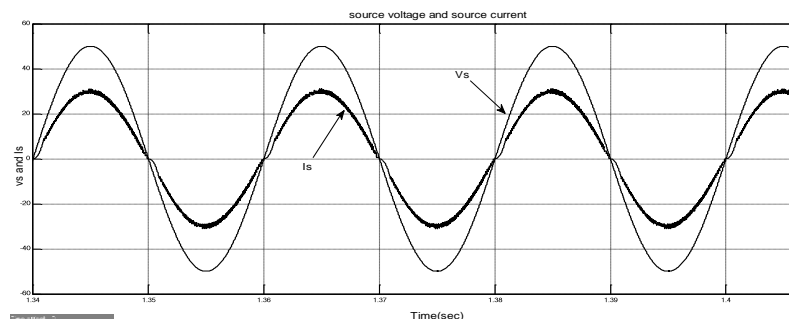

Figure6 (a)

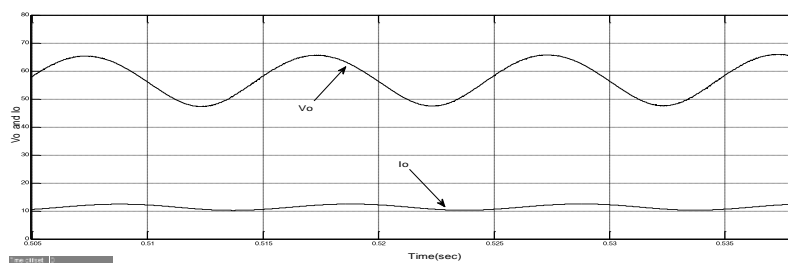

Figure6 (b)

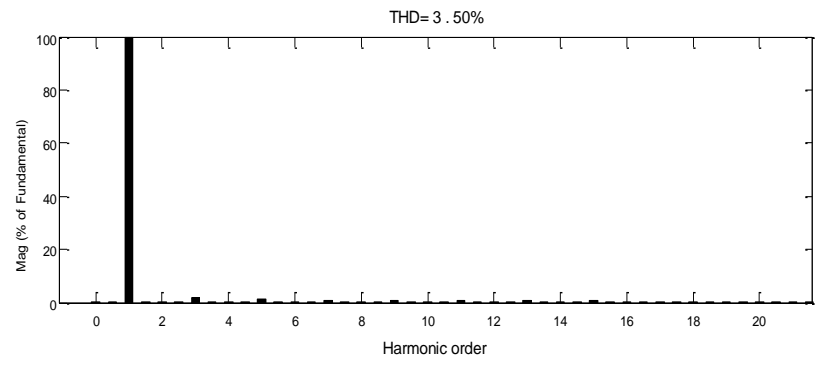

Figure6 (c)

Fig.6 (a) SourceVoltage and Current (with Input Filter)

(b) Output voltage and current.

(c)Harmonic Spectrum of source current (with input filter)

\section{EXPERIMENTAL RESULTS}

As part of experimentation and testing of the hardware developed, various waveforms were observed and tested in the power circuit using dSPACE arrangement for generating pulses using embedded HCC. The experimental results (figure 7) closely matched the simulation results with permissible deviations owing to non-idealities in the hârdware implementation.

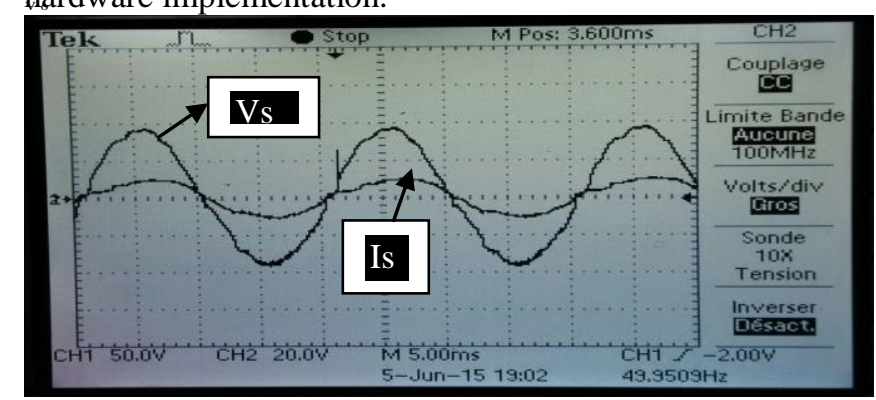

Figure7. Source Voltage Vs and Source Current Is (sinusoidal)

Experimental results generate a sinusoidal voltage and current waveform which shows reduced harmonic distortion in the input current and voltage, Also voltage and current waveform is in phase with each other ,thus shows input power factor unity.

\section{COMPARISON OF VARIOUS TOPOLOGIES}

TABLE 1 shows the comparative Analysis Of various IPQC Topologies.

For same load, the THD of conventional bridge rectifier is as high as $30 \%$ making it clear that PFC techniques gives a comparatively better power quality and same is verified by the experimental results also showing improved power quality in terms of reduced THD and improved input power factor to unity.

Table 1 Comparative Analysis of Various IPQC Topologies

\begin{tabular}{|l|l|l|l|l|}
\hline Type & BUCK & BOOST & FLYB & Boost \\
\hline
\end{tabular}


Available online at www.ijrat.org

\begin{tabular}{|c|c|c|c|c|}
\hline $\begin{array}{l}\text { of } \\
\text { IPQC }\end{array}$ & $\begin{array}{l}\text { Converte } \\
r \\
\text { (In DCM) }\end{array}$ & $\begin{array}{l}\text { Converte } \\
r \\
\text { (In DCM) }\end{array}$ & $\begin{array}{l}\text { ACK } \\
\text { Conv } \\
\text { erter } \\
\text { (In } \\
\text { DCM } \\
\text { ) }\end{array}$ & $\begin{array}{l}\text { converter } \\
\text { (In CCM) } \\
\text { UNIDIREC } \\
\text { T IONAL }\end{array}$ \\
\hline $\begin{array}{l}\text { \%age } \\
\text { THD } \\
\text { Of } \\
\text { Sourc } \\
\text { e } \\
\text { Curre } \\
\text { nt }\end{array}$ & $1.62 \%$ & $3.23 \%$ & $\begin{array}{l}4.30 \\
\%\end{array}$ & $3.50 \%$ \\
\hline PFC & $\begin{array}{l}\text { Low PFC } \\
\text { property }\end{array}$ & $\begin{array}{l}\text { Better } \\
\text { Self PFC } \\
\text { property }\end{array}$ & $\begin{array}{l}\text { Good } \\
\text { PFC } \\
\text { prope } \\
\text { rty }\end{array}$ & $\begin{array}{l}\text { Excellent } \\
\text { Self PFC } \\
\text { property }\end{array}$ \\
\hline $\begin{array}{l}\text { No. Of } \\
\text { Device } \\
\text { s Used }\end{array}$ & $\begin{array}{l}\text { 5- } \\
\text { Diodes, } \\
\text { 1-IGBT }\end{array}$ & $\begin{array}{l}\text { 5- } \\
\text { Diodes, } \\
\text { 1-IGBT }\end{array}$ & $\begin{array}{l}5- \\
\text { Diode } \\
\mathrm{s}, 1- \\
\text { IGBT } \\
, \\
\text { Linea } \\
\mathrm{r} \\
\text { Trans } \\
\text { forme } \\
\mathrm{r}\end{array}$ & $\begin{array}{l}\text { 5- Diodes, } \\
\text { 1-IGBT }\end{array}$ \\
\hline $\begin{array}{l}\text { Electri } \\
\text { cal } \\
\text { Isolati } \\
\text { on }\end{array}$ & $\mathrm{NO}$ & NO & YES & $\mathrm{NO}$ \\
\hline $\begin{array}{l}\text { Applic } \\
\text { ation }\end{array}$ & $\begin{array}{l}\text { Dc } \\
\text { Motor } \\
\text { Drive } \\
\text { \&Power } \\
\text { Supplies }\end{array}$ & $\begin{array}{l}\text { Power } \\
\text { Supplies }\end{array}$ & $\begin{array}{l}\text { Dc } \\
\text { Motor } \\
\text { Drive } \\
\text { s \& } \\
\text { SMP } \\
\text { S }\end{array}$ & $\begin{array}{l}\text { Power } \\
\text { Supplies }\end{array}$ \\
\hline
\end{tabular}

\section{CONCLUSION}

An exhaustive investigation and analysis of IPQCs has been presented in this paper to explore a wide perspective of various configurations of IPQCs to researchers, designers, application engineers, and end users of ac-dc converters. Simulation results show that by using IPQCs, the total harmonic distortion has reduced from $30 \%$ to $3.5 \%$. The source voltage and source current are in phase thus power factor being unity. The results obtained thus comply with the IEEE-519 standard of harmonic control.

\section{REFERENCES}

[1] Sokal, Nathan O, "A Capacitor-Fed, VoltageStep-Down, Single-phase, Non- Isolated
Rectifier." Proc. of IEEE Applied Power Electronics Conference, APEC'98. pp. 208- 215, 1998.

[2] Redl, Richard, "An Economical Single-phase Passive Power-Factor-Corrected Rectifier: Topology, Operation, Extensions, and Design for Compliance." Proc. of IEEE Applied Power Electronics Conference, APEC'98. pp. 454-460, 1998.

[3] Mohan, N., T. M. Undeland, and W. P. Robbins, Power Electronics, Converters, Applications, And Design, 2nd Edition, John Wiley and Son, Inc., New York, 1995..

[4] Abdul Hamid Bhat and Pramod Agarwal, "Improved Power Quality AC/DC Converter," Intechopen, April 11, 2011.

[5] M. H. Rashid, Power Electronics: Circuits, Devices, and Applications, 2nd ed. Englewood Cliffs, NJ: Prentice-Hall, 1993.

[6] G. Seguier, Power Electronic Converters AC/DC Conversion. New York: McGraw-Hill, 1986.

[7] J. G. Kassakian, M. F. Schecht, and G. C. Verghese, Principles of Power Electronics. Reading, MA: Addison-Wesley, 1991.

[8] Bhim Singh, Brij N. Singh, Ambrish Chand, Kamal Al-Haddad, Ashish Pandey, and Dwarka P. Kothari, 'A Review of Single-Phase Improved Power Quality AC-DC Converters', IEEE TRANSACTIONS ON INDUSTRIAL ELECTRONICS, VOL. 50, NO. 5, OCTOBER 2003

[9] R. J. King, "Analysis and design of an unusual unity-power-factor rectifier," IEEE Trans. Ind. Electron., vol. 38, pp. 126-134, Apr. 1991.

[10] H. Endo, T. Yamashita, and T. Sugiura, "A high power-factor buck converter,"mProc. IEEE PESC'92, 1992, pp. 1071-1076.

[11]E. Destobbeleer, G. Seguier, and A. Castelain, "AC-DC converter minimizing induced harmonics in industrial power systems," IEEE Trans. Power Electron., vol. 2, pp. 320-327, Oct. 1987.

[12] Yao-Ching Hsieh, Ming-Ren Chen and HungLiang Cheng, (2011) 'An Interleaved Flyback Converter Featured With Zero-Voltage Transition', IEEE Transactions On Power Electronics, Vol.26, No.1, pp79-84. 